\title{
Physiological quality of tomato seeds treated with polymers in combination with paclobutrazol ${ }^{1}$
}

\author{
Édila Maria de Rezende ${ }^{2 *}$, João Almir Oliveira ${ }^{2}$, Everson Reis Carvalho ${ }^{3}$, \\ Aline da Consolação Sampaio Clemente ${ }^{2}$, Gustavo Evangelista Oliveira ${ }^{4}$
}

\begin{abstract}
In tomatoes production system, etiolation is the main cause of seedlings loss. Some inhibitors, such as paclobutrazol (PBZ), have been used to reduce this problem. This study aimed to evaluate the effect of different doses of paclobutrazol, with and without polymer association, at different degrees of permeability, on the physiological quality of seeds. Seeds of two tomato cultivars, Ozone and Paronset, were treated with four concentrations of paclobutrazol $(0,0.004,0.008$ and $0.016 \mathrm{~g} \mathrm{~mL}$ a.i.10 $\mathrm{g} \mathrm{seeds}^{-1}$ ), and combined with three fixatives (water, P1 and P2). After the treatments, germination test, germination speed index test and cold test were carried out, and after five months of seed storage, the analyzes were repeated. The increase in PBZ dose reduces both germination percentage and germination speed index. After storage, the product acts differently on seed germination. The synthetic polymers, in the dose used in this study, are effective in PBZ fixation on the seeds coat, but do not reduce the harmful effect of PBZ on seed germination.
\end{abstract}

Index terms: Lycopersicum sculentum, fixatives, PBZ.

\section{Qualidade fisiológica de sementes de tomate tratadas com paclobutrazol em associação com polímeros}

\begin{abstract}
RESUMO - No sistema de produção de tomates, o estiolamento é a principal causa de perdas de mudas. Alguns inibidores, como o paclobutrazol (PBZ), têm sido utilizados para reduzir esse problema. No presente trabalho, objetivou-se avaliar o efeito de diferentes doses de paclobutrazol com e sem associação de polímeros com diferentes graus de permeabilidade, sobre a qualidade fisiológica das sementes. Foram utilizadas sementes de duas cultivares de tomate, Ozone e Paronset, tratadas com quatro doses de paclobutrazol $\left(0 ; 0,004 ; 0,008\right.$ e 0,016 mL i.a. $\left.10 \mathrm{~g}_{\text {sementes }}{ }^{-1}\right)$, combinadas com três fixadores (água; P1 e P2). Após o tratamento, foram efetuados os teste de germinação, índice de velocidade de germinação e teste frio, e após cinco meses de armazenamento das sementes as análises foram repetidas. O aumento na dose de PBZ reduz a porcentagem de germinação e o índice de velocidade de germinação. Após o armazenamento, o produto atua de forma diferente na porcentagem de germinação das sementes. Os polímeros sintéticos na dosagem utilizada são eficientes na fixação do PBZ no tegumento das sementes, mas não reduzem o efeito prejudicial do PBZ na germinação das sementes.
\end{abstract}

Termos para indexação: Lycopersicum sculentum, fixadores, PBZ.

\section{Introduction}

Brazil places $3^{\text {rd }}$ in tomato production world ranking, behind only the United States and Spain. The tomato production in Brazil in 2014 was 4.302.777,00 tons, which means that its productive chain has a strong relevance in

${ }^{1}$ Submitted on 05/25/2016. Accepted for publication on 09/16/2017. ${ }^{2}$ Departamento de Agricultura, Universidade Federal de Lavras, Caixa Postal 3037, 37200-000 - Lavras, MG, Brasil.

${ }^{3}$ Instituto de Ciências Agrárias, Universidade Federal de Uberlândia, 38500-000 Monte Carmelo, MG, Brasil. national agribusiness (FAO, 2014). In tomato production, specifically for "in natura" consumption, sowing is carried out in trays, with subsequent transplanting of seedlings. However, one of the main problems observed in this phase is the rapid vegetative growth of the aerial part (etiolation). This unbalance results in the formation of fragile, elongated

${ }^{4}$ Syngenta Seeds Ltda, 13825-000 - Holambra, SP, Brasil. *Corresponding author <em_rezende@hotmail.com> 
seedlings, with smaller hypocotyl diameter, few roots and higher susceptibility to biotic and abiotic stresses, factors that may lead to loss of these seedlings (Seleguini et al., 2013).

The use of growth regulators is one of the practices that have been tested to reduce and minimize seedlings etiolation. Among them, paclobutrazol - PBZ has been highlighted by its efficiency (Nascimento et al., 2003). PBZ belongs to the triazoles group and it acts reducing the biosynthesis of gibberellins and, consequently, reducing stem growth without compromising cell differentiation and without causing phytotoxicity (Oliveira et al., 2014).

PBZ applied via seed treatment is one of the safest and most effective options to obtain more compact plants, without residual content in the fruit (Magnitsky et al., 2006). However, as PBZ acts reducing the synthesis of gibberellin, deleterious effects on seed germination may be observed.

The efficiency of seed treatment with PBZ depends on where it is fixated. The best option is on the seed coat, avoiding direct contact of the product with the embryo. Thereby, coating techniques have been tested as an application alternative (Seleguine et al., 2013).

In works with seed treatment, the soaking time was tested for solutions containing different doses of PBZ, in association or not with coating techniques. In these works, the authors observed that, despite finding satisfactory results regarding plant height, PBZ affected the germination and emergence of seedlings (Arcari et al., 2012; Melo et al., 2014). However, these studies do not establish standards for usage and do not define the limit between the efficient and the harmful PBZ dose, which reinforces the need for further studies, especially ones associated to polymers with different permeability.

Despite the effectiveness of the product in tomato cultivation, application technologies that avoid direct contact with the embryo, especially at the initial germination stages, and that can fix the product on seed coat must be adjusted. Therefore, the aim of this work was to evaluate the effect of different doses of paclobutrazol with and without polymers association, in different degrees of permeability, on the physiological quality of seeds.

\section{Material and Methods}

The study was realized in the Central Laboratory of Seeds at the Universidade Federal de Lavras - UFLA / DAG, Lavras, MG, Brazil. Seeds of two tomato hybrids (Ozone and Paronset) treated with four PBZ doses $(0,0.004,0.008$ and $0.016 \mathrm{~mL}$ a.i. $)$ were used in combination with three fixatives: water, mediumpermeability polymer - P1 (D438) and high-permeability polymer - P2 (L036). The polymers were used at the minimum dose recommended by the manufacturer $\left(5 \mathrm{~mL} \cdot \mathrm{kg}\right.$ of seeds $\left.{ }^{-1}\right)$, diluted 1:2 (pol:water).

To prepare the solutions, in the treatments tested with polymers, the polymer was mixed with water and submitted to stirring table for five minutes. Then, the commercial product $\left(\right.$ Cultar $250 \mathrm{SC}^{\circledR}$ ) was added and stirred again for another 10 minutes. In order to have the same volume of solution in all treatments $(0.214 \mathrm{~mL})$, it was added as much water as necessary. The treatments were carried out in $10 \mathrm{~g}$ of seeds (4000 seeds).

The volume of the solution was distributed as evenly as possible over $25 \mathrm{~cm}$-diameter petri dishes. Then, the seeds were added, and the petri dishes were capped and manually shaken for about four minutes. After the treatments, part of the seeds was submitted to the tests and the other part was packed in paper bags and stored in cold room $\left(10{ }^{\circ} \mathrm{C}, 50 \%\right.$ $\mathrm{RH})$ for five months. After this period, the tests were repeated to verify the action of the product after the storage time.

To evaluate the physiological quality of the seeds, a germination test was carried out. Four replications of 50 seeds each were placed in acrylic boxes (gerbox), using blotting paper that had been watered with 2.5 times its dry weight as a substrate. The gerboxes were maintained in BOD chambers, at $20-30{ }^{\circ} \mathrm{C}$ for 21 days, with a photoperiod of 12 hours. The results were expressed as percentage (Brasil, 2009).

Simultaneously to the germination test, the germination speed index (GSI) was measured. Daily countings were performed and the seeds were considered germinated when there was radicle protrusion. The index estimative was obtained by using the formula proposed by Maguire (1962). The germination count (number of normal seedlings) was carried out at 14 days and, since there were still a large number of non-germinated seeds, the test was extended to 21 days. The seeds that remained from this test were submitted to the tetrazolium test, according to the methodology described in Brasil (2009), to evaluate their viability.

In addition to the germination test, the cold test was also performed on 200 seeds distributed in four replications. Soil and sand $(1: 1)$ were used as substrate in acrylic gerboxes, in the volume of $3 / 4$ of the box height $(\sim 300 \mathrm{~g})$. Substrate moisture was adjusted to $70 \%$ of water retention capacity, as prescribed by the International Seed Test Association (ISTA, 1995). After seeding, the gerboxes were sealed with film plastic and kept in cold chamber at $10{ }^{\circ} \mathrm{C}$ for seven days. Then, they were transferred to a BOD incubator set for a 12-hour photoperiod, at alternate temperature $20-30{ }^{\circ} \mathrm{C}$, where they remained for another seven days. The results were expressed as percentage of normal emerged plants.

It was used a completely randomized design with four replications, in a $3 \times 4$ factorial scheme, which means 3 fixatives 
x 4 PBZ doses. After obtaining the data, preliminary analyzes were carried out to verify the conditions for the analysis of variance. The data were submitted to individual analysis of variance for each hybrid and for each season, and means were compared with the Scott-Knott test, at a significance level of $5 \%$. Polynomial regression analyzes were performed to describe the effects of paclobutrazol concentrations. The analyzes were realized using SISVAR ${ }^{\circledR}$ software (Ferreira, 2011).

\section{Results and Discussion}

\section{Physiological quality tests of the tomato seeds right after treatments}

In the cultivar Ozone, there was significance for the doses in the variables percentage of germination $(G \%)$ and germination speed index (GSI). In neither variables there was a relationship between the doses of paclobutrazol and the polymer used. In the cultivar Paronset, there were significance for the dose in the variable GSI and interaction between the factors dose and polymer in the variable $\mathrm{G} \%$. This shows that the action of the product may vary according to the genotype.

In the cultivar Ozone, the percentage of germination (G\%) significantly decreased only at the dose 0.016 ( $\mathrm{mL}$ a.i.) $(10 \text { g.seeds })^{-1}$. This reduction was of $15 \%$ (Figure 1A). In the cultivar Paronset, all doses tested reduced the percentage of seeds germination. The largest reduction was of approximately $70 \%$ at the dose 0.016 ( $\mathrm{mL}$ a.i.). ( $10 \mathrm{~g}$.seeds) $)^{-1}$ associated with P1 (Figure 1B).

Despite the low percentages of germination at the maximum PBZ doses tested, the remaining seeds were still viable according to the tetrazolium test. This shows that the seeds were dormant, possibly due to the inhibitory effect of PBZ on gibberellin production.

The doses of 0.008 and 0.016 ( $\mathrm{mL}$ a.i.) $(10 \text { g.seeds })^{-1}$ associated with the synthetic polymers (P1 and P2), promoted a greater reduction in the percentage of germination, when compared to the same doses in association with water (Table 1). This result evidences that the polymers possibly fix the product on the seed coat. However, this fixation may lead to a greater absorption of PBZ during imbibition, which can be harmful to seeds germination. On the other hand, Melo et al. (2014) observed that in film-coated tomato seeds treated with PBZ, the polymer was not efficient in fixating PBZ on the seed coat.

The reduction in the percentage of seed germination is expected due to the increase in paclobutrazol dose, since the active principle has an anti-gibberellin action (Silva et al., 2003); Melo et al. (2014) observed a reduction of up to $35 \%$ in germination potential of tomato seeds treated with this compound. As gibberellin acts directly on seed germination by activating hydrolytic enzymes necessary to the process, a
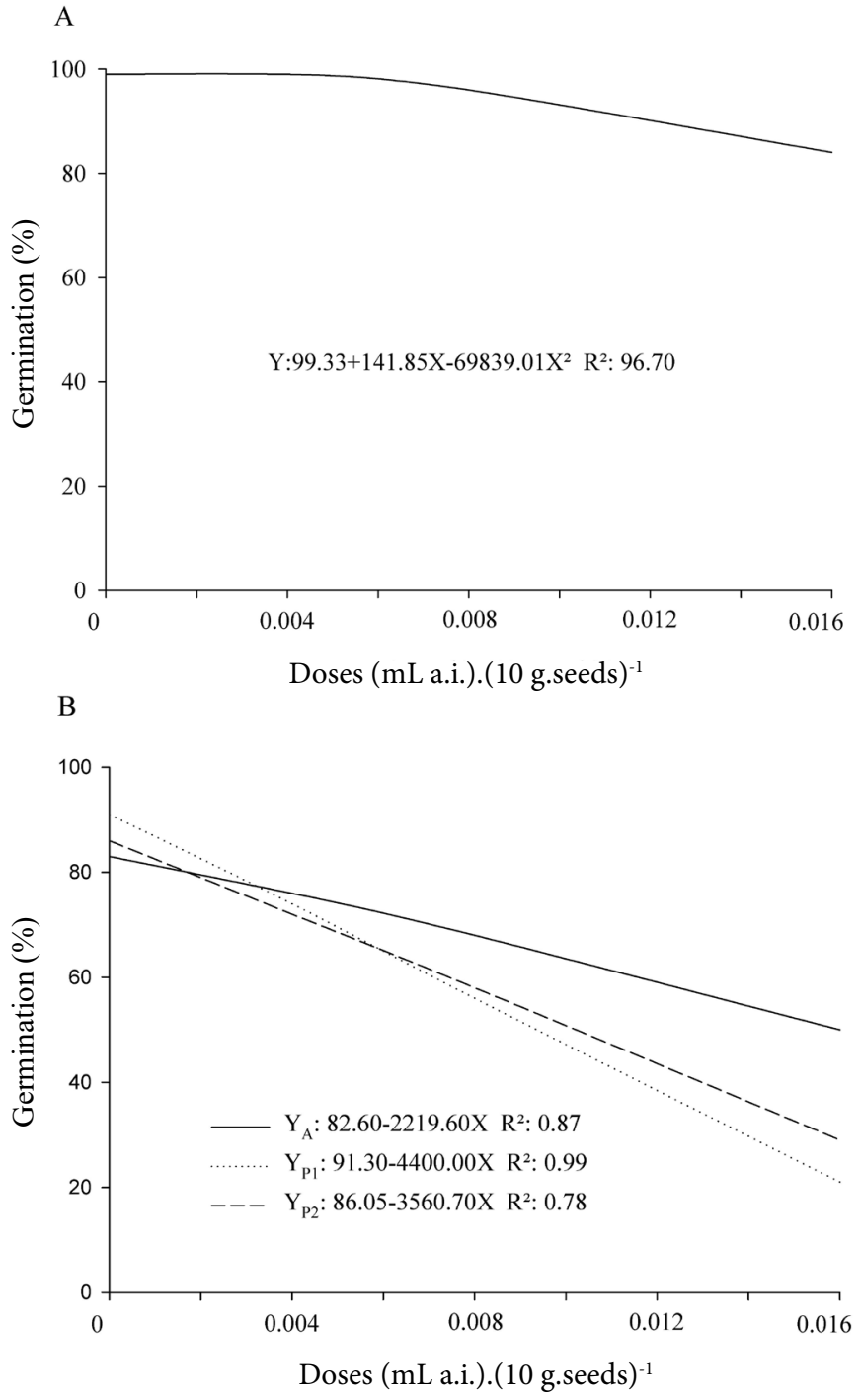

Figure 1. Percentage of germination of tomato seeds, cultivar Ozone (A) and cultivar Paronset (B), treated with different doses of paclobutrazol.

Table 1. Percentage of germination of Paronset tomato seeds treated with different doses of paclobutrazol and associated with three types of fixatives: water (A); medium-permeability polymer (P1) and highpermeability polymer (P2).

\begin{tabular}{ccccc}
\hline \multirow{2}{*}{ Fixative } & \multicolumn{4}{c}{ Doses $\left(\mathrm{mL}\right.$ a.i.). $(10 \text { g.seeds })^{-1}$} \\
\cline { 2 - 5 } & 0 & 0.004 & 0.008 & 0.016 \\
\hline A & $85 \mathrm{a}$ & $67 \mathrm{~b}$ & $72 \mathrm{a}$ & $46 \mathrm{a}$ \\
P1 & $91 \mathrm{a}$ & $75 \mathrm{a}$ & $55 \mathrm{~b}$ & $21 \mathrm{c}$ \\
P2 & $87 \mathrm{a}$ & $83 \mathrm{a}$ & $40 \mathrm{c}$ & $29 \mathrm{~b}$ \\
\hline
\end{tabular}

*Means followed by the same letter in the column do not differ statistically at $5 \%$ probability by the Scott-Knott test. 
reduction of germination is expected when the concentration of paclobutrazol increases.

All the tested doses caused reduction on seed germination rates of both cultivars (Figure 2). These results match those obtained by Melo et al. (2014), who tested the PBZ imbibition period in association with film-coating. The authors verified a reduction in the ESI as the paclobutrazol concentration increased, and they associated this result with the longer imbibition time, when an unwanted contact between the PBZ and the embryonic axis may occur before germination, which reduces the concentration of endogenous gibberellins. Thus, the synthesis of enzymes involved in germination and embryo axis elongation are jeopardized (Taiz and Zeiger, 2013), causing delay in the germination process or inducing secondary dormancy in seeds.

In the cold test, seeds were submitted to high humidity and low temperature. In these conditions, they do not germinate and only imbibe, thus staying more time exposed to the product. So, it was expected that greater damages would occur to seeds germination/emergence of both cultivars. However, there was a significant effect for the factors dose and polymer only in the cultivar Paronset.

The reduction in the percentage of emergence of Paronset seedlings in the cold test occurred only at the maximum dose tested, which was of approximately $15 \%$ (Figure 3). The synthetic polymers caused an increase in the percentage of seedlings emerged in the cold test (Table 2). This probably happened due to the physical barrier provided by the polymers, which may have prevented excessive water and/or product (PBZ) inflow during the incubation period at low temperatures.

\section{Physiological quality tests of tomato seeds after five months storage}

The factors dose and polymers were not significant for the variables percentage of germination $(\mathrm{G} \%)$ and germination speed index (GSI), in the germination test of cultivar Ozone seeds that had undergone five months storage. In opposition, the data obtained for Paronset cultivar seeds showed that there was a significant effect of the isolated factors polymer and dose over the GSI, and an interaction between them on germination.

The percentage of germination ( $\mathrm{G} \%$ ) significantly decreased when PBZ was associated with P2 (Figure 4A). However, this reduction was significant only at the dose $0.016(\mathrm{~mL}$ a.i.) $(10$ g.seeds ${ }^{-1}$ ) (Table 3 ). This polymer has the property of being highly permeable, which may have favored the entry of PBZ into the seed. It is also worth mentioning that the non-germinated seeds were still viable according to the tetrazolium test.

The dose 0.016 (mLa.i.) $\left(10\right.$ g.seeds $\left.\mathrm{s}^{-1}\right)$ of PBZ administered in the cultivar Paronset reduced the ESI, thus jeopardizing

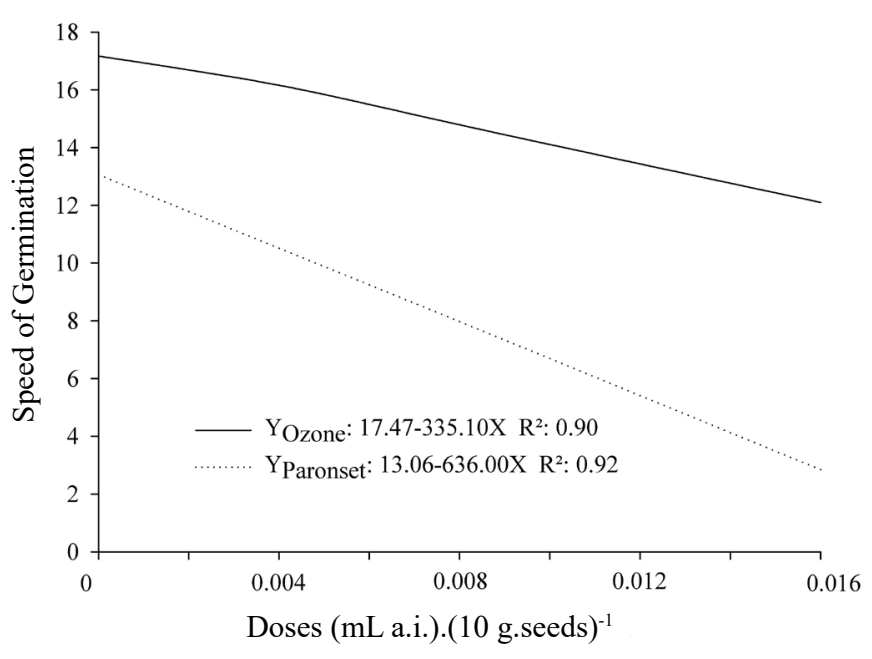

Figure 2. Germination speed index of tomato seeds treated with different doses of paclobutrazol.

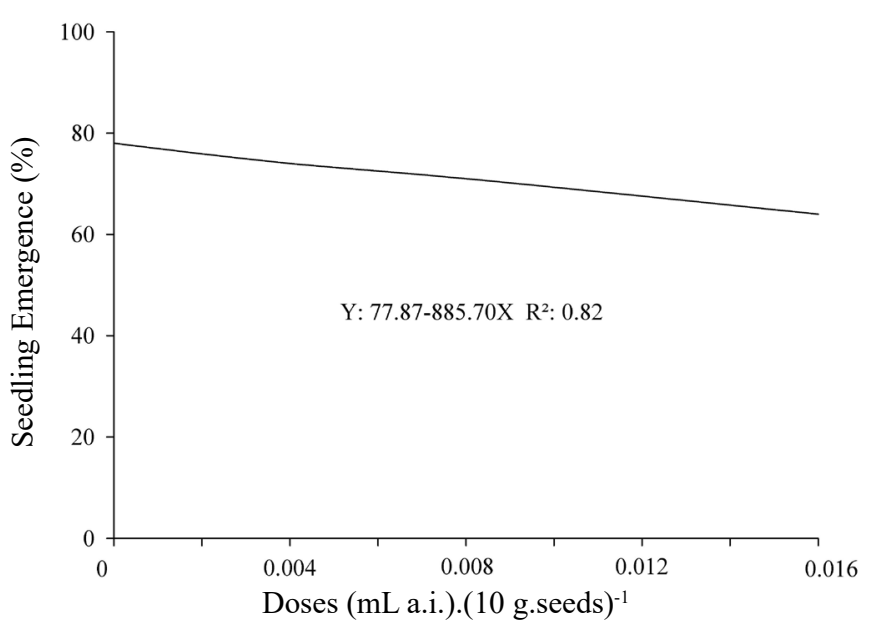

Figure 3. Percentage of emergence of Paronset tomato plants obtained in the cold test, from seeds treated with different doses of paclobutrazol.

Table 2. Percentage of emergence of plants obtained in the cold test, from Paronset tomato seeds associated with three types of fixatives: water (A); mediumpermeability polymer $(\mathrm{P} 1)$ and high-permeability polymer (P2).

\begin{tabular}{cc}
\hline Fixatives & Emergence (\%) \\
\hline A & $56 \mathrm{~b}$ \\
P1 & $77 \mathrm{a}$ \\
P2 & $82 \mathrm{a}$ \\
\hline
\end{tabular}

*Means followed by the same letter do not differ statistically at $5 \%$ probability by the Scott-Knott test. 

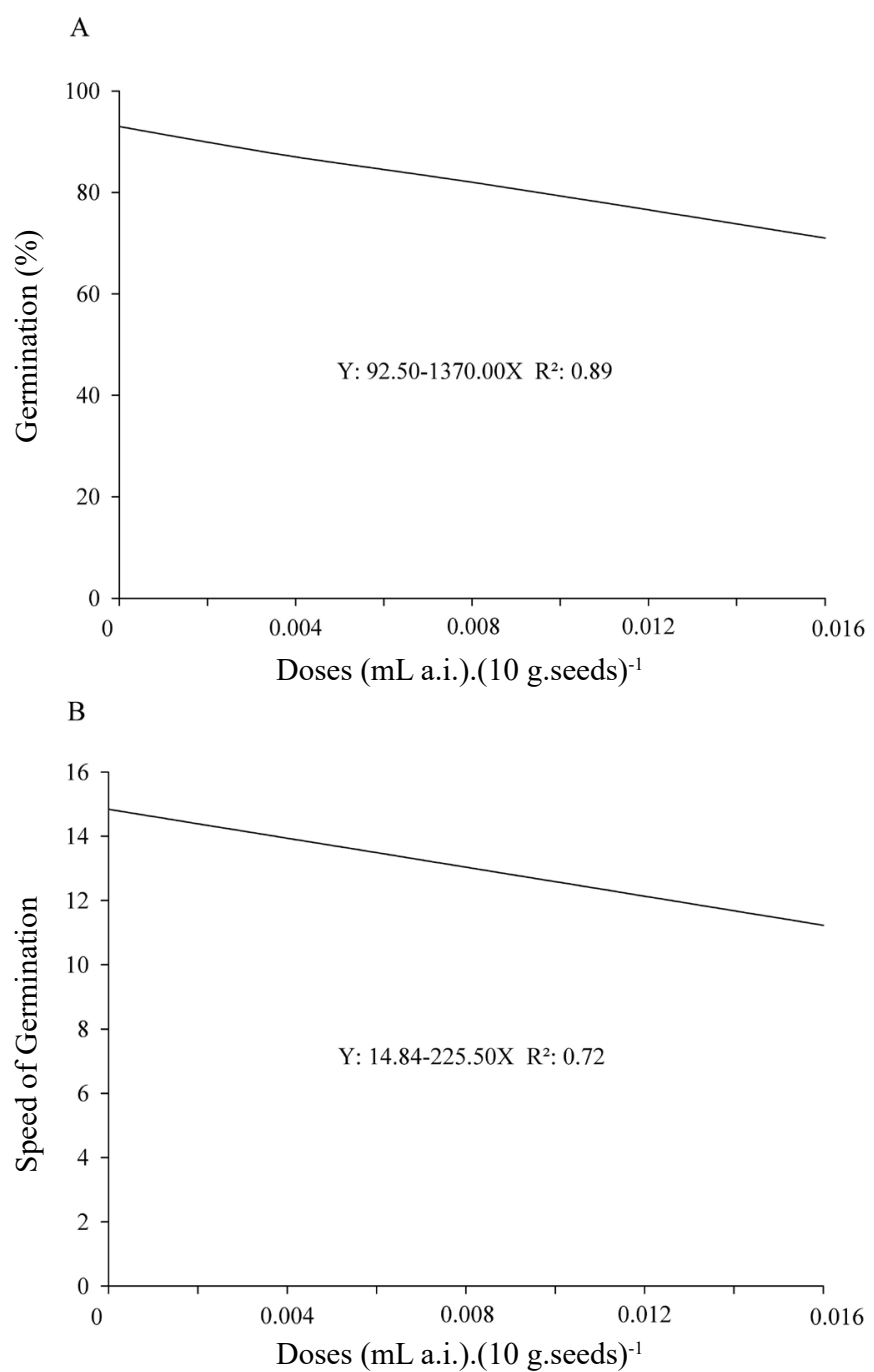

Figure 4. Percentage of germination (A) and germination speed index (B) of Paronset tomato seeds, after being treated with different doses of paclobutrazol and submitted to five months storage.

Table 3. Percentage of seed germination of Paronset tomato seeds treated with different doses of $\mathrm{PBZ}$ associated with three types of fixatives: water (A); mediumpermeability polymer (P1) and high-permeability polymer (P2).

\begin{tabular}{ccccc}
\hline \multirow{2}{*}{ Fixatives } & \multicolumn{4}{c}{ Doses $(\mathrm{mL} \text { a.i.).(10 g.seeds })^{-1}$} \\
\cline { 2 - 5 } & 0 & 0.004 & 0.008 & 0.016 \\
\hline A & $90 \mathrm{a}$ & $87 \mathrm{a}$ & $87 \mathrm{a}$ & $89 \mathrm{a}$ \\
P1 & $92 \mathrm{a}$ & $84 \mathrm{a}$ & $85 \mathrm{a}$ & $83 \mathrm{a}$ \\
P2 & $92 \mathrm{a}$ & $87 \mathrm{a}$ & $82 \mathrm{a}$ & $71 \mathrm{~b}$ \\
\hline
\end{tabular}

*Means followed by the same letter in the column do not differ statistically at $5 \%$ probability by the Scott-Knott test.
Table 4. Means of the germination speed index (GSI) of Paronset tomato seeds associated with three types of fixatives: water (A); medium-permeability polymer (P1) and high-permeability polymer (P2).

\begin{tabular}{cc}
\hline Fixatives & GSI \\
\hline A & $14.82 \mathrm{a}$ \\
P1 & $12.72 \mathrm{~b}$ \\
P2 & $12.25 \mathrm{~b}$ \\
\hline
\end{tabular}

*Means followed by the same letter do not differ statistically at $5 \%$ probability by the Scott-Knott test.

seed vigor (Figure 4B). However, this reduction was lower than the one observed in seeds that were treated and submitted to the germination test right after (Figure 2B). According to these results, it can be verified that in this cultivar, PBZ acted less aggressively in the inhibition of gibberellin after the seeds were treated and stored for five months.

When the polymer 2 was used as fixative for the $0.016(\mathrm{~mL}$ a.i.) $(10 \text { g.seeds })^{-1} \mathrm{PBZ}$ dose in this cultivar, the germination speed decreased (Table 4). This shows that this polymer may promote a greater absorption of PBZ, which can lead to a reduction in gibberellin production, as reported by Pereira et al. (2010). Another possibility is that the polymer hindered water absorption, which consequently reduced germination speed. As stated by the cold test results for both cultivars, no significant effect was observed for any of the factors after five months of storage of the seeds.

\section{Conclusions}

Higher paclobutrazol doses applied to the tomato seeds cause reduction in uniformity and in the percentage of germination and in the germination speed index of both cultivars. There are also differences in behavior between the two cultivars, regarding the action of PBZ;

After storage, seeds of the cultivar Ozone show no response to the treatment with paclobutrazol in the germination test, and the cultivar Paronset present a reduction in the percentage of germination less drastic than in the test performed right after the treatment of the seeds;

Synthetic polymers, in the dose used in this study, are efficient in fixing PBZ on the seed coat, but do not reduce the harmful effect of PBZ on seed germination.

\section{Acknowledgments}

UFLA, CNPq, Syngenta and Incotec. 


\section{References}

ARCARI, F.S.; SELEGUINI, A.; ABADIA.; HAROLD, C.A.; LOSI, J.M. Uso do paclobutrazol no tratamento de sementes para produção de mudas de tomate rasteiro. Horticultura Brasileira, v.30, n.2, p.S162-S167, 2012. http://www.abhorticultura.com.br/ eventosx/trabalhos/ev_6/A5243_T7927_Comp.pdf

BRASIL. Ministério da Agricultura, Pecuária e Abastecimento. Regras para análise de sementes. Ministério da Agricultura, Pecuária e Abastecimento. Secretaria de Defesa Agropecuária. Brasília: MAPA/ACS, 2009. 395p. http://www.agricultura.gov.br/arq_editor/ file/2946_regras_analise_sementes.pdf

FERREIRA, D.F. Sisvar: A computer statistical analysis system. Ciência e Agrotecnologia, v.35, n.6, p.1039-1042, 2011. <http:// www.scielo.br/pdf/cagro/v35n6/a01v35n6.pdf>

FAO. Food and Agriculture Organization of the United Nations. Fao Stat Statistical Database. 2014. <http://www.fao.org/faostat/ en/\#data/QC $>$ Accessed on: Feb.23 ${ }^{\text {th }}, 2017$.

ISTA. International Seed Test Association. Handbook of vigour test methods. 3. ed. Zürich: ISTA, 1995.117p.

MAGNITSKY, S.V.; PASIAN, C.C.; BENNETT, M.A.; METZGER, J.D. Effects of soaking cucumber and tomato seeds in paclobutrazol solutions on fruit weight, fruit size, and paclobutrazol level in fruits. HortScience, v.41, n.6, p.1446-1448, 2006. <http://hortsci. ashspublications.org/content/41/6/1446.full.pdf>

MAGUIRE, J.D. Speed of germination-aid in selection and evaluation for seedling emergence and vigor. Crop Science, v.2, n.1, p.176-177, 1962. <https://dl.sciencesocieties.org/publications/cs/ abstracts/2/2/CS0020020176>

MELO, A.P.C.; SELEGUINI, A.; VELOSO, V.R.S. Peliculização de sementes de tomate associada ao paclobutrazol. Bragantia, v.73, n.2, p.123-129, 2014. http://www.scielo.br/pdf/brag/v73n2/aop_ brag_0123.pdf
NASCIMENTO, W.M.; SALVALAGIO, R.; SILVA, J.B.C. Condicionamento químico do crescimento de mudas de tomate. Horticultura Brasileira, v.21, n.2, p.1-3, 2003. Suplemento.

OLIVEIRA, H.T.B.; PEREIRA, E.C.; MENDONÇA, V.; SILVA, R.M.S.; LEITE, G.A.; DANTAS, L. L.G. R. Produção e qualidade de frutos de mangueira "Tommy Aktins" sob doses de Paclobutrazol. ACSA - Agropecuária Científica no Semi-Árido, v.10, n.3, p.89-92, 2014. Disponível em: <http://revistas.ufcg.edu.br/acsa/index.php/ ACSA/article/view/585/pdf>

PEREIRA, C.E.; OLIVEIRA, J.A.; NETO, J.C.; MOREIRA, F.M.S.; VIEIRA, A.R. Tratamentos, inseticida, peliculização e inoculação de sementes de soja com rizóbio. Revista Ceres, v.57, n.5, p.653-658, 2010. <http://dx.doi.org/10.1590/S0034-737X2010000500014>.

SELEGUINI, A.; FARIA JÚNIOR, M.J.A.; BENETT, K.S.S.; LEMOS, O.L.; SENO, S. Estratégias para produção de mudas de tomateiro utilizando paclobutrazol. Semina: Ciências Agrárias, v.34, n.2, p.539-548, 2013. <http://www.uel.br/revistas/uel/index.php/ semagrarias/article/view/9321/12557>

SILVA, C.M.M.S.; FAY, E. F.; JONSSON, C.M. Paclobutrazol: regulador de crescimento vegetal. In: SILVA, C.M.M.S.; FAY, E. F. (Ed.). Impacto ambiental do regulador de crescimento vegetal paclobutrazol. Jaguariúna: Embrapa-CNPMA, 2003. p.11-16. Documentos, $30<\mathrm{http}$ //www.infoteca.cnptia.embrapa.br/bitstream/ doc/14522/1/documentos30.pdf $>$

TAIZ, L.; ZEIGER, E. Fisiologia vegetal. 5.ed. Porto Alegre:Artmed, 2013. 954p. 